\title{
A comprehensive model of seismic velocities for the Bay of Mecklenburg (Baltic Sea) at the North German Basin margin: implications for basin development
}

\author{
Michael Schnabel $^{1}$ (D) Vera Noack $^{2}$ (D) Niklas Ahlrichs $^{2,3}$ (D) $\cdot$ Christian Hübscher $^{3}$ (D)
}

Received: 15 September 2020 / Accepted: 26 March 2021 / Published online: 15 April 2021

(c) The Author(s) 2021

\begin{abstract}
The geometry of sedimentary basins is normally described by the interpretation of seismic reflectors. In addition to that, rock properties of the sedimentary successions between these reflectors give further insight into the subsurface geology. Here, we present a model for the Bay of Mecklenburg, situated at the northeastern margin of the North German Basin. The model consists of eight layers; it covers seismic velocities of sediments from the Neogene down to the base of the Permian Zechstein. We use eight seismic profiles for model building and apply seismic migration velocity analysis in combination with pre-stack depth migration. The results are interval velocities down to a depth of $5000 \mathrm{~m}$. A further aim of the study is to investigate the sensitivity of these indirectly deduced velocities in comparison to direct measurements within drill holes. The velocities from this study are in good agreement with earlier results from vertical seismic profiling at a nearby well. Cenozoic and Mesozoic strata within the Bay of Mecklenburg show clear depth-dependent velocity trends. A comparison of these trends with predicted compaction trends shows that burial anomalies within Lower Triassic units are significantly higher than in Upper Cretaceous units. This finding could be explained by a greater amount of erosion during Upper Jurassic/ Lower Cretaceous times than during Cenozoic times. The Zechstein layer shows a decreasing interval velocity with increasing thickness. Our study demonstrates that seismic velocities deduced from surface-based measurements are of high value in areas with sparse drilling coverage.
\end{abstract}

\section{Introduction}

Seismic imaging provides crucial insight for understanding of sedimentary basin development. Seismic data is normally measured in the time domain. The prerequisite for a quantitative data analysis, e.g. in terms of balanced reconstruction, is proper depth imaging, which requires usage of reliable seismic velocities to display lateral varying structures at the correct depth (e.g. Etgen et al. 2009). Seismic velocity variations within particular stratigraphic units are further indicators for differences in lithology of sedimentary rock units. In addition, compaction (reduction in porosity) of the

Michael Schnabel

michael.schnabel@bgr.de

BGR, Stilleweg 2, 30655 Hannover, Germany

BGR, Wilhelmstr. 25-30, 13593 Berlin, Germany

Institute of Geophysics, Center for Earth System Research and Sustainability, Universität Hamburg, Bundesstraße 55, 20146 Hamburg, Germany sediments also influences the seismic velocities during the deposition history of a sedimentary basin.

Many diagenetic processes can cause an increase of seismic velocity within sedimentary layers. The most important influence emerges from increasing pressure (e.g. Densley et al. 2000), which is often related to burial depth. These processes are generally thought to be irreversible (see discussion in Corcoran and Doré 2005). This means that the sedimentary strata will keep its diagenetic stage from the maximum burial of the basin development, and later uplift of sediments will not result in a decrease of seismic velocities. These cases will show a positive velocity anomaly with respect to the current burial depth (Japsen 1993). The amount of this anomaly is proportional to the negative burial anomaly (Japsen 1998) and could therefore be used to estimate the maximum depth of burial. This principle was already used by John (1975) and is still a valid tool to measure vertical movements in a sedimentary basin (Japsen 2018). Up to now, most of the earlier studies discussing seismic velocities are based on the analysis of well logging data (e.g. Japsen 1998; Jaritz et al. 1991; Scherbaum 1982). 
Well data provides high-resolution velocity information with depth, but only in one dimension. Hence, the lateral resolution is restricted to the number of available wells and interpolation in between. In contrast to that, seismic data provides a very high lateral resolution along the acquisition profiles, while the vertical resolution is limited by the wavelength of the used signal.

The primary aim of this study is to derive and discuss a spatial varying velocity model for the Bay of Mecklenburg (Baltic Sea, northeastern North German Basin (NGB)) using migration velocity analysis (MVA). Eight marine seismic profiles were used for velocity analysis. Due to the small spatial extent of the area of investigation (approx. $50 \times 80 \mathrm{~km}$, see Fig. 1), a lateral effect of lithological changes within the sedimentary layers is not expected. However, the base of the Zechstein shows a huge variability in depth within this area, ranging from more than 5000 to less than $3000 \mathrm{~m}$ below sea level. Therefore, the Bay of Mecklenburg is a perfect place to estimate the depth-dependent effects of seismic velocity.

The second focus of this study is to link the seismostratigraphy from the Bay of Mecklenburg to an adjacent well, which allows us to refine the lithological interpretation.
Thus, our method focuses on both construction of velocity depth functions for individual units in areas with little well control and gaining insight in the reconstruction of basin development.

\section{Physical setting}

The Bay of Mecklenburg is situated at the northeastern NGB and is part of the intracontinental Southern Permian Basin spreading across Central Europe (Fig. 1). The northeastern end of the Bay spatially correlates with the NGB margin (Ahlrichs et al. 2020, and references there in). The NGB was affected by repeated phases of subsidence and uplift during its complex basin history from Palaeozoic to Cenozoic times (e.g. Maystrenko et al. 2008). In the Bay of Mecklenburg, the structural style is affected by salt movement and the development of some salt pillows (Hansen et al. 2007; Zöllner et al. 2008; Scheck-Wenderoth et al. 2008; Hübscher et al. 2010; Ahlrichs et al. 2020). These salt structures consist of late Permian Zechstein evaporites, which were deposited during arid climate conditions and

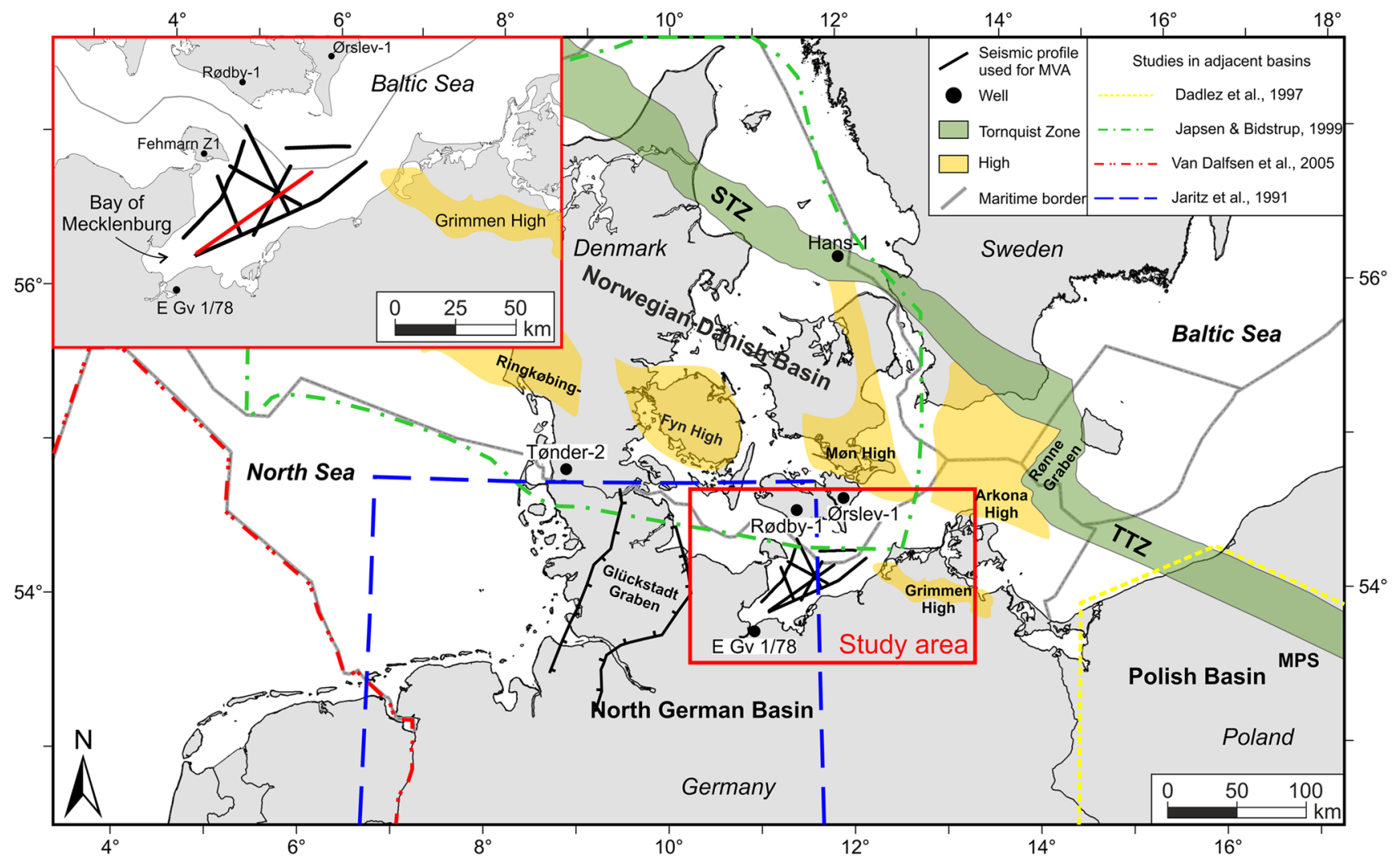

Fig. 1 Structural overview of the North German Basin and adjacent sedimentary basins. Inset shows area of investigation with seismic profiles used for the MVA in the Bay of Mecklenburg. Line BGR16224 is highlighted in red (Fig. 4b). Study areas of publications on velocity analysis discussed in the text are shown. STZ, Sorgenfrei-
Tornquist Zone; TTZ, Tornquist-Teisseyre Zone; MPS, Mid-Polish Swell. Compiled after Nielsen and Japsen (1991); Hoth et al. (1993); Schlüter et al. (1997b); Baldschuhn et al. (2001); Mazur et al. (2006); Scheck-Wenderoth et al. (2008); Seidel et al. (2018); Erlström (2020); Grimmen High according to Schlüter et al. (1997a) 
repeated restricted seawater influx. In the deeper basin of the NGB, the Zechstein evaporite sequence contains seven cyclic sequences made of anhydrite, halite, clay and carbonates (Tucker 1991; Strohmenger et al. 1996). The overlying Triassic successions (Buntsandstein, Muschelkalk and Keuper) are deposited during rapid subsidence (Fig. 2). The Bay of Mecklenburg represented a local depocenter during deposition of the Buntsandstein and Muschelkalk successions (e.g. Scheck and Bayer 1999). In the Late Triassic, basin configuration changed and the depocenter migrated towards the south. In the Bay of Mecklenburg, subsidence decreased towards the end of the deposition of the Keuper successions. Simultaneously, the initiation of salt pillow growth led to locally increased Keuper thickness in rim synclines (e.g. Scheck and Bayer 1999). From the Jurassic onwards, subsidence rates further decreased (Kossow and Krawczyk 2002) (Fig. 2). During Middle to Upper Jurassic times, the development of the Central North Sea Dome (Ziegler 1990b; Underhill and Partington 1993) caused large-scale uplift, leading to erosion of much of the Jurassic strata in the Bay of Mecklenburg (Zöllner et al. 2008; Ahlrichs et al. 2020). Sedimentation was re-established in the Lower Cretaceous (Albian). A phase of relative tectonic quiescence persisted until the Upper Cretaceous accompanied by the deposition of chalk and limestones (Kossow and Krawczyk 2002). The Upper Cretaceous onset of the Africa-IberiaEurope convergence induced compressional stress within the study area (Kley and Voigt 2008). As a result, the area was again affected by uplift, erosion and the reactivation of pre-existing basement faults as reverse faults. Uplift of the nearby Grimmen High was approximately 400-500 m (Kossow and Krawczyk 2002; Ahlrichs et al. 2020). During the Paleogene, the study area underwent gentle subsidence in conjunction with the rapid subsidence of the North Sea Basin (Ziegler 1990b). Further phases of uplift in the study area are reported for the Palaeocene, late Eocene and Oligocene. However, their existence and spatial extent in the Baltic sector of the NGB are an aspect of recent discussion and remain unclear (Kley 2018). In the Neogene, large-scale uplift of the western and eastern margins of the North Sea Basin is observed (Japsen 1998).

According to the onshore well information near the Bay of Mecklenburg (Hoth et al. 1993), the Cenozoic successions within the working area consist of terrestrial and shallow marine clastic sediments. These are mainly gravel, clay, marl, siltstone and claystone. The underlying successions of limestone and chalk of the Upper Cretaceous and marl of the Lower Cretaceous (Albian) deposits represent marine conditions. Sedimentary rocks of Berrasian up to the lower part of the Albian stage as well as nearly the entire Jurassic deposits are absent. Remnants of Lower Jurassic claystones are preserved especially in rim synclines of salt pillows. Below the Jurassic, or where absent below the Lower Cretaceous successions, the Triassic Keuper consists mostly of sandstones and mudstones representing predominantly terrestrial and fluviatile conditions. Due to marine ingressions in the Upper and Lower Keuper, small beds of evaporites are present within the successions. The underlying Muschelkalk successions consist of limestones and marlstones with intercalated evaporates representing marine conditions. The Buntsandstein successions below are characterized by intercalated claystones and siltstones deposited in fluviatil and terrestrial conditions. The Upper Buntsandstein succession is characterized by evaporitic deposits which represents marine conditions. The underlying marine Zechstein successions contain five major cyclothems of anhydrite, halite, claystones and carbonates.

\section{Materials and methods}

The multichannel seismic data set was acquired in 2016 using the research vessel Maria S. Merian (Hübscher et al. 2017). By minimizing the near-trace offset to $33 \mathrm{~m}$, the acquisition configuration was optimized to record also seismic reflections from shallow horizons at a water depth less than $25 \mathrm{~m}$. Additionally, the active cable length of $2700 \mathrm{~m}$ (216 channels) provided sufficient offset to perform velocity analysis down to several 1000-m depth. The seismic source array consisted of eight GI-SOURCE 210 airguns. The source signal (dominant frequency of $80 \mathrm{~Hz}$ ) delivered a high vertical resolution in the range of 6 to $14 \mathrm{~m}$, while the clustering of eight guns provided deep signal penetration down to a depth of more than $5000 \mathrm{~m}$. The source station interval of $25 \mathrm{~m}$ resulted in a 54-fold common midpoint coverage.

We analysed eight seismic profiles with a total length of $336 \mathrm{~km}$ (Fig. 1). The pre-processing consisted of geometry binning, designature and bandpass filtering, spherical divergence correction, preliminary velocity analysis, stacking and migration in time domain. Multiple reflections have been suppressed using a predictive deconvolution in the poststack domain.

To resolve lateral velocity variations, we applied migration velocity analysis (MVA). The benefits of MVA compared to classical normal moveout (NMO) analysis have initially been demonstrated by Al-Yahya (1989). During MVA, common offset gathers are pre-stack depth-migrated, resulting in common reflection point (CRP) gathers along the profile (Stork 1992). For a selected horizon, the overlying velocity model is adjusted until the offset-dependent reflections for this horizon are flat for all (migrated) CRP gathers. This process was iteratively repeated for all horizons (top-down). The resulting velocities reflect the lateral changes of each individual layer. We performed this analysis for eight layers, from the seafloor down to the base of 
Fig. 2 Litho-stratigraphic chart of the NGB (modified after Ahlrichs et al. (2020)). Layer numbers (in red) refer to the here presented migration velocity analysis (in red), corresponding regional reflectors after Reinhardt (1993). Litho-stratigraphic subdivision according to Menning (2018). Layer thickness and seismic velocity are based on well Gv 1/78 (Feßer 1980). The cumulative subsidence of the northern NGB margin (Kossow and Krawczyk 2002) is shown together with major uplift events (Bachmann et al. 2008)

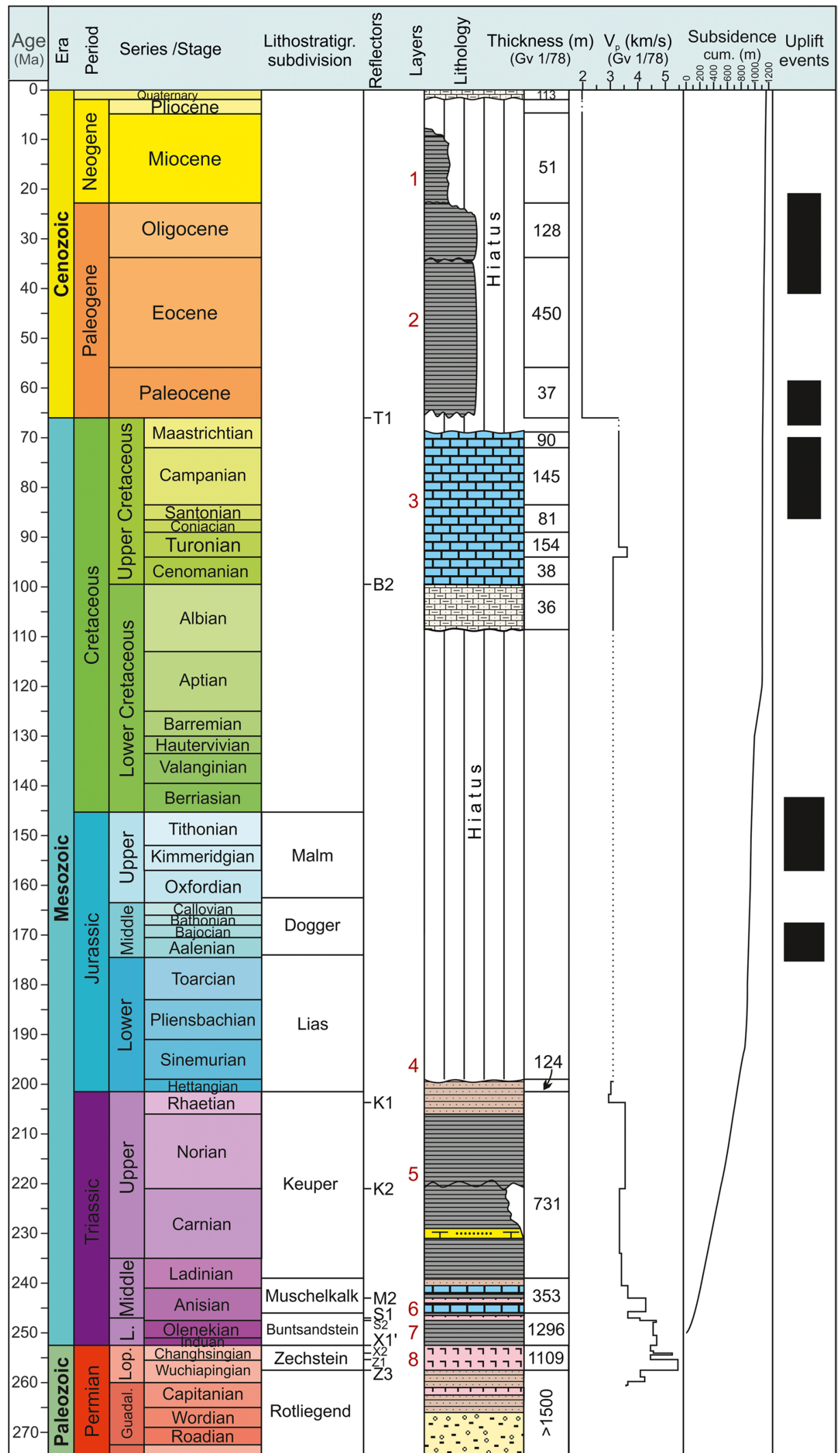

Legend
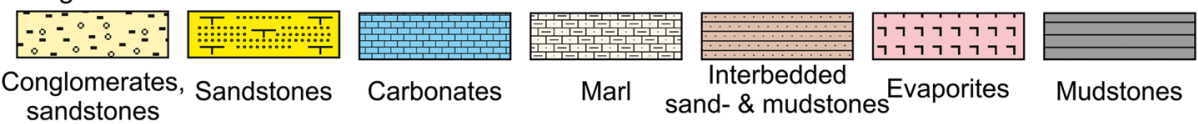

Mudstones 
the Zechstein layer. In the following, these layers are called seismic layers.

To investigate the sensitivity of the MVA analysis, we varied the final velocity field by $2 \%$ and migrated the data again. Figure 3 shows a single migrated CRP gather from line BGR16-212. A velocity variation of $2 \%$ produces a significant and visible moveout effect for the far offset traces.

Additionally, this study uses results from vertical seismic profiling (VSP) in the nearby well Gv 1/78 (Fig. 1). The VSP covered a depth down to $5900 \mathrm{~m}$ and 26 reflectors have been identified (Feßer 1980). Measured differences in travel time have been converted to interval velocity.

As the porosity of sedimentary rocks decreases during deeper burial, seismic interval velocity increases. This process is considered irreversible, and thus, measured velocity is a proxy for maximum burial depth. Post-depositional uplift reduces burial depth and leads to higher velocities than expected at this depth. This is referred to as a velocity anomaly (see e.g. Japsen et al. 2007 for more details). By MVA, we obtain lateral variant interval velocities of individual seismic layers at varying depth. We compare the depth-dependent velocity trend derived from the MVA with published reference velocity-depth trends from well data in adjacent areas and identify velocity anomalies. Based on the normal velocity trend, the velocity anomaly represents an approximation of the amount of post-depositional uplift of that seismic layer.

\section{Results}

The velocity analysis resulted in lateral variable interval velocities for all seismic layers. Figure 4 shows the results for profile BGR16-224, which is located in the centre of the Bay of Mecklenburg (red line in Fig. 1). Within Fig. 4a, the interval velocities from well Gv $1 / 78$ (black line) and the main reflectors from the VSP analysis are plotted. Additionally, this box shows the result from the MVA at CDP 13,200 of profile BGR16-224 (red line in Fig. 4a). The absolute depth of post-Permian strata is variable due to the varying thickness of the Zechstein layer caused by salt tectonics. We chose the position along the line (CDP 13,200) to provide a good match between the seismic layers and the well (for a detailed discussion see Ahlrichs et al. (2020)). Both curves in Fig. 4a show a similar trend and high correlation. The vertical seismic profiling within well Gv 1/78 has a much higher resolution than the surface-based measurement along profile BGR16-224. With the MVA technique, only layers with a thickness exceeding $100 \mathrm{~m}$ could be resolved (Fig. 4a).

The information from well Gv 1/78 (Fig. 2) allows us to link eight seismic layers to the stratigraphy of the sedimentary successions in the Bay of Mecklenburg. The identified bounding reflectors in the MVA are based upon the seismostratigraphic framework in Reinhardt (1993). The uppermost layer from the VSP has an interval velocity of $1976 \mathrm{~m} / \mathrm{s}$, while the first layer for the MVA has a velocity of $1931 \mathrm{~m} / \mathrm{s}$. The base of seismic layer 2 corresponds to reflector T1 (transgression Cenozoic). According to the well information, the seismic layers 1 and 2 on top of the T1 reflector represent sedimentary rocks of the Cenozoic successions. At a depth of $1570 \mathrm{~m}$, the vertical seismic profiling of $\mathrm{Gv} 1 / 78$ shows a pronounced velocity increase (from 2940 to $3540 \mathrm{~m} / \mathrm{s}$ ) corresponding to the reflector $\mathrm{K} 1$, situated within the Upper Keuper succession. Therefore, seismic layer 3 most probably contains Upper Cretaceous units, while seismic layer 4 may contain Cenomanian, Hettangian and Rhaetian units. From 1570-m depth (reflector K1) to 2265-m depth (reflector M2 - internal reflection of the middle Muschelkalk) data from $\mathrm{Gv}$ 1/78 shows quite uniform interval velocities ranging between 3330 and $3640 \mathrm{~m} / \mathrm{s}$, while the corresponding seismic layer 5 from the MVA has a velocity of $3465 \mathrm{~m} / \mathrm{s}$. At reflector M2, a sharp velocity increase of about $640 \mathrm{~m} / \mathrm{s}$ is encountered. Therefore, seismic layer 5 consists mainly of sedimentary rocks of the Keuper successions, while seismic layer 6 contains Muschelkalk and possibly Upper Buntsandstein sedimentary rocks. According to Ahlrichs et al. (2020), the reflector S1 (top Salinarröt, lowermost Upper Buntsandstein) represents the boundary between seismic layers 6 and 7. The well data shows uniform velocities between 2800 (reflector S2 - top of Middle Buntsandstein) and 3775-m depth (reflector $\mathrm{X}^{\prime}{ }^{\prime}$ - top of Zechstein) in the range of 4550 to $4680 \mathrm{~m} / \mathrm{s}$. The corresponding seismic layer 7 from the MVA has an interval velocity of $4723 \mathrm{~m} / \mathrm{s}$. Accordingly,
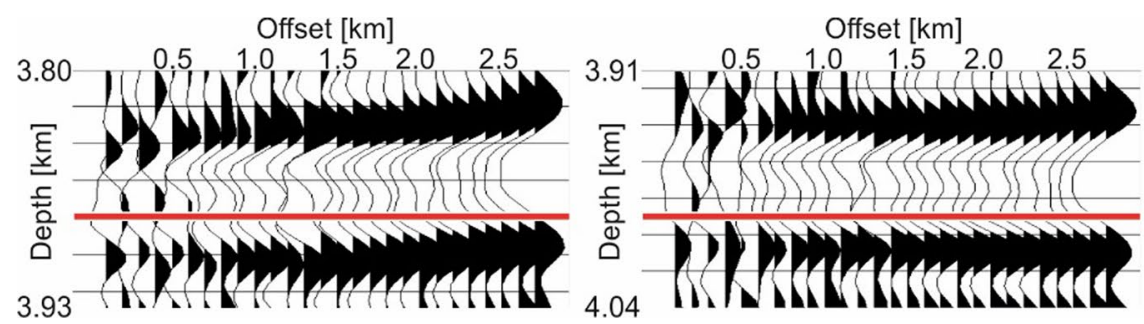

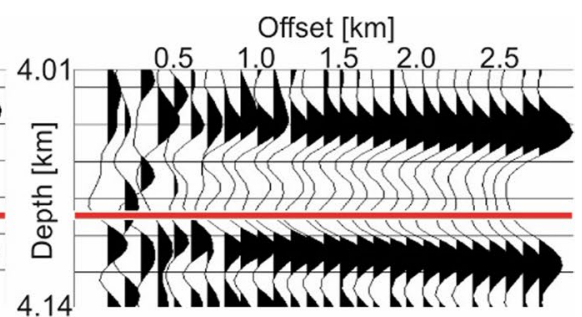

Fig. 3 Migrated gathers showing the base of Zechstein at CDP 16,300. The middle panel is migrated with the final velocity field. For the left panel, the velocity field was decreased by $2 \%$, while the velocity field for the right panel was increased by $2 \%$. Both variations cause significant moveout effects 


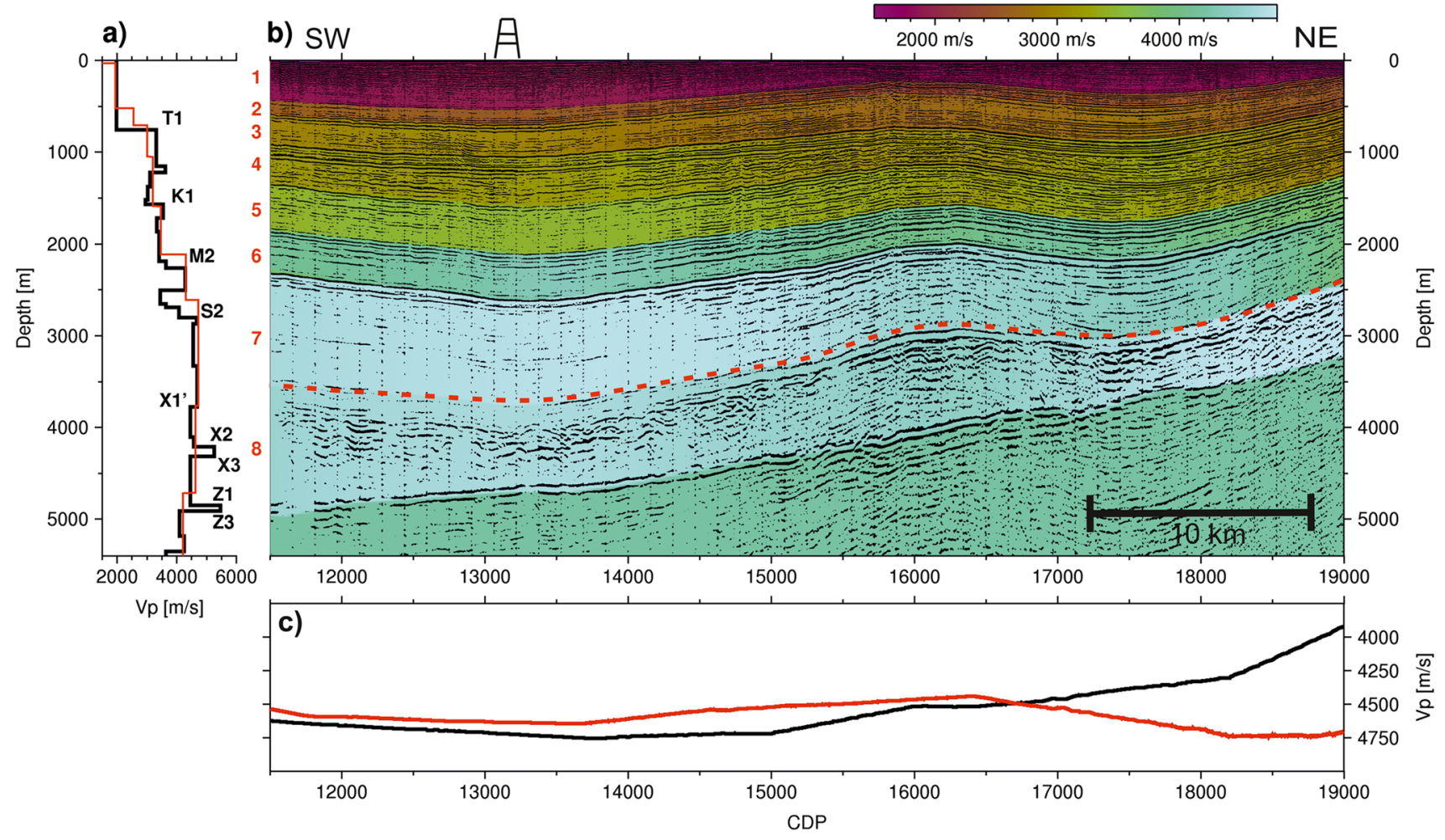

Fig. 4 Seismic profile BGR16-224 and the resulting velocity distribution. a Black curve shows results of a vertical seismic survey at well Gv 1/78 (Grevesmühlen), key reflectors are marked. Red curve shows the 1D velocity function at CDP 13,200 (the projected position is highlighted by the drilling rig). The profile in panel $\mathbf{b}$ is displayed with vertical exaggeration of 4 . The boundary between seismic layer 7 and 8 is marked by the red stippled line. Red digits between pan-

seismic layer 7 represents sedimentary rocks of Middle and Lower Buntsandstein successions. The base of seismic layer 8 is the prominent $\mathrm{Z} 3$ reflector (base of Zechstein), characterized by a pronounced negative impedance contrast between Zechstein and Rotliegend successions. Therefore, seismic layer 8 represents the Zechstein successions. At the drill site, the Zechstein shows thin zones ( $105 \mathrm{~m}$ between reflectors $\mathrm{X} 2$ and $\mathrm{X} 3$ and $60 \mathrm{~m}$ between reflectors $\mathrm{Z} 1$ and Z3) of increased velocities $(5250 \mathrm{~m} / \mathrm{s}$ and $5455 \mathrm{~m} / \mathrm{s}$, respectively) which are described as anhydrite. The dominant part of the Zechstein interval shows velocities ranging from 4460 to $4565 \mathrm{~m} / \mathrm{s}$. The MVA delivered $4630 \mathrm{~m} / \mathrm{s}$ for seismic layer 8 at CDP 13,200 (Fig. 4a).

To investigate the velocity variations with depth, we used the MVA results from all 8 seismic profiles. For each CDP, the MVA delivered a mean interval velocity for each seismic layer. Due to the basin configuration, the base of the Zechstein dips from $3000 \mathrm{~m}$ in the northeast to more than $5000 \mathrm{~m}$ in the southwest. As a consequence, the Zechstein layer and all other layers of the overburden are encountered at a varying depth range. For instance, the mean depth of layer 7 within the area of investigation is between 1540 els $\mathbf{a}$ and $\mathbf{b}$ mark numbers of seismic layer. $\mathbf{c}$ Lateral velocity variation within seismic layer 7 (black) and 8 (red). Layer 7 has a velocity maximum at its deepest part around CDP 14,000, while the velocity decreases towards the northeast. Layer 8 has a velocity minimum at the thickest part of the Zechstein around 16,000, while the velocity increases towards the southeast and the northwest

and $3330 \mathrm{~m}$; even the shallow layer 2 covers a depth range between 100 to $750 \mathrm{~m}$ (see Table 1). This allows for a depthdependent analysis of the observed velocities. For each CDP, we assigned the interval velocity of each layer $\left(V_{z}\right)$ to the mean depth of this layer $(Z)$ at this location. According to Eq. (1), we determined a linear relationship for layers 1 to 7 (e.g. Marsden 1992). The resulting values for starting velocity $V_{0}$ and gradient $k$ are given in Table 1 .

$V_{z}=V_{0}+k Z$

To account for the fact that the velocity increase with depth is greatest for shallow formations, we calculated a velocity-depth-relationship for seismic layers 1 to 5 according to Eq. (2) suggested by Faust (1951). The resulting function (displayed as black line in Fig. 5) shows a reasonable fit to a depth of about $2000 \mathrm{~m}$.

$V_{Z}=602 * Z^{1 / 4.272}$

Within seismic layer 8 (Zechstein), no relation between depth and velocity can be seen. Instead, this velocity $\left(V_{\text {salt }}\right)$ inversely correlates to the thickness $\left(D_{\text {salt }}\right)$ of the Zechstein layer (Fig. 6). This effect is already visible within Fig. 4c. 
Table 1 Resulting values for starting velocity $\mathrm{V}_{0}$ and gradient $\mathrm{k}$ for layers 1 to 7

\begin{tabular}{llllll}
\hline Layer & $V_{0}(\mathrm{~m} / \mathrm{s})$ & $k\left(\mathrm{~s}^{-1}\right)$ & Velocity range $(\mathrm{m} / \mathrm{s})$ & $\begin{array}{l}\text { Range of mean } \\
\text { depth }(\mathrm{m})\end{array}$ & Stratigraphy \\
\hline 1 & 1730 & 0.72 & $1765-1980$ & $50-350$ & Cenozoic \\
2 & 2160 & 0.56 & $2215-2580$ & $100-750$ & Cenozoic \\
3 & 2165 & 1.01 & $2255-3195$ & $90-1020$ & Upper Cretaceous \\
4 & 2320 & 0.71 & $2560-3380$ & $340-1490$ & Cenomanian, Rhaetian \\
5 & 2330 & 0.67 & $2730-3655$ & $600-1980$ & Keuper \\
6 & 2845 & 0.60 & $3420-4325$ & $960-2470$ & Muschelkalk \\
7 & 3590 & 0.36 & $4145-4790$ & $1540-3330$ & Buntsandstein \\
\hline
\end{tabular}

Column 5 gives the range of the mean depth for each layer. The last column contains the dominant stratigraphic units for each layer
Here, the Zechstein layer has the lowest velocity within the thick pillow at CDP 16,000, while the velocity decreases within the thinner parts towards southwest and the northeast. A linear fit for all eight seismic lines results in Eq. (3) (displayed as red line in Fig. 6):

$V_{\text {salt }}=4750-0.18 * D_{\text {salt }}$

\section{Discussion}

\section{Comparison to existing onshore data}

For the onshore area of the northwestern North German Basin, Jaritz et al. (1991) presented an analysis of seismic velocities, based on about 1000 well velocity logs. They deduced linear velocity laws (Eq. (1)) for 10 post-Permian rock units. The resulting velocity gradients ( $k$ in Eq. (1)) are constant for each unit, while the starting velocity $V_{0}$ varies laterally. For Cenozoic layers, their gradient amounts to $0.7 \mathrm{~s}^{-1}$, comparable to our results for seismic layers 1 and 2. The Upper Cretaceous of Jaritz et al. (1991) shows the highest gradient with values between 0.9 and $1.2 \mathrm{~s}^{-1}$. Our work also found the highest gradient within seismic layer $3\left(1.01 \mathrm{~s}^{-1}\right.$, Table 1). Seismic layer 4 is dominated by a huge hiatus and contains thin layers of Cretaceous, Jurassic and maybe Upper Triassic sedimentary rocks - so a comparison to existing data is not possible. Jaritz et al. (1991) characterize the Jurassic/Triassic successions by a decreasing gradient in the range of 0.2 to $0.7 \mathrm{~s}^{-1}$, which is in good agreement with our results for seismic layer 5 to 7. For the Middle and Lower Buntsandstein, the gradient

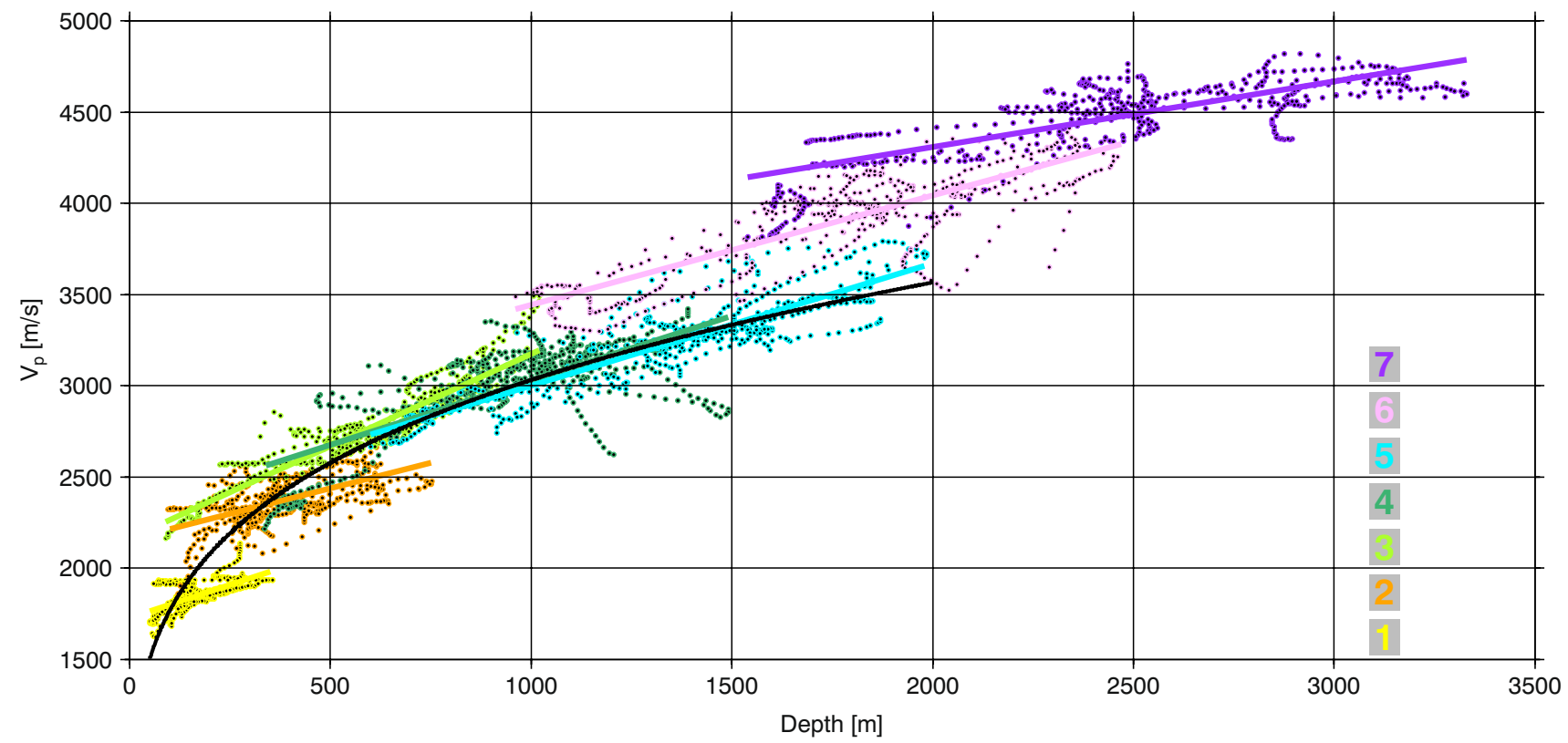

Fig. 5 Interval velocity $\mathrm{V}_{\mathrm{p}}$ versus mean depth of the seismic layers. Coloured numbers correspond to numbers of seismic layers. Straight lines represent solutions to Eq. (1). Black curve displays Eq. (2) 
Fig. 6 Velocity within the Zechstein layer versus thickness of this layer. Red curve displays the linear relation of this work (Eq. (3)), blue curve covers the Dutch onshore (Wong et al. 2004)

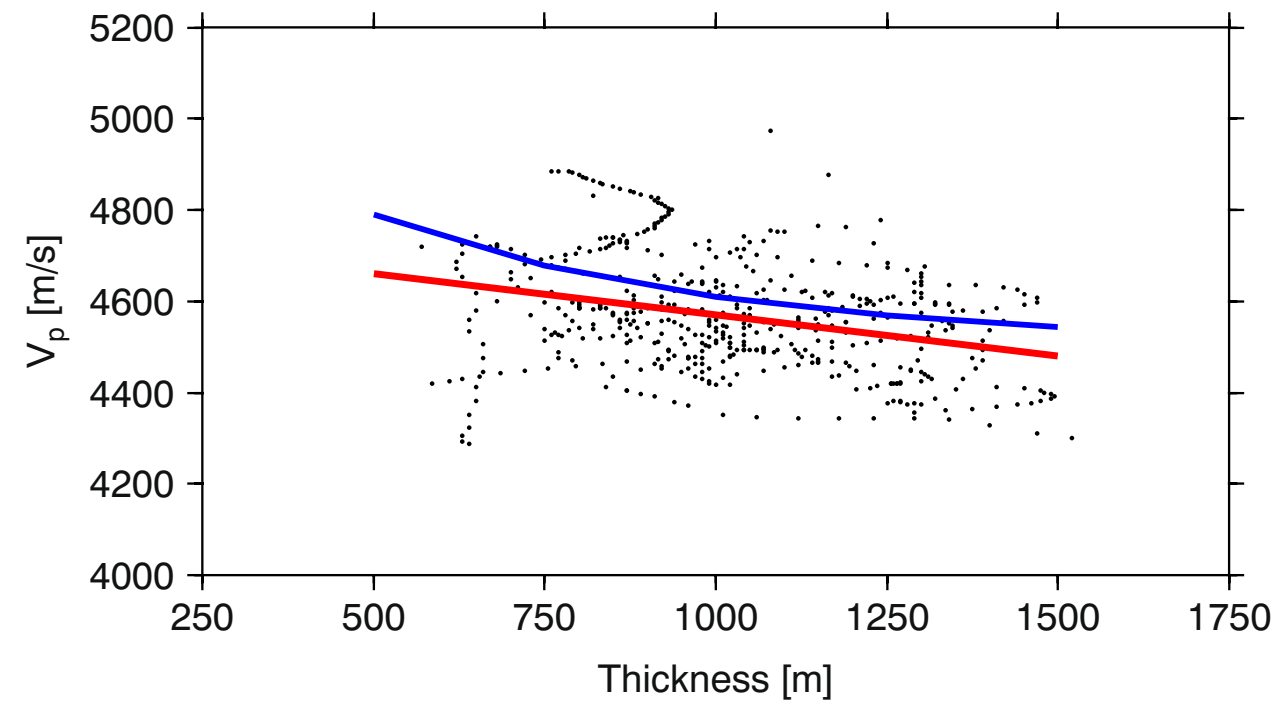

given by Jaritz et al. (1991) is $0.45 \mathrm{~s}^{-1}$, slightly higher than our results for seismic layer $7\left(0.36 \mathrm{~s}^{-1}\right.$, Table 1$)$. On the other hand, corresponding values for $V_{0}$ differ for both investigations. Therefore, the resulting velocity-depth-relations show a mismatch of not more than $5 \%$ at the depth interval between 2000 and $3000 \mathrm{~m}$ (see dark blue and black lines in Fig. 7b). Jaritz et al. (1991) used only onshore well data for their analysis, but interestingly they found an increase of seismic velocities in the vicinity of the Bay of Mecklenburg in the range of $500 \mathrm{~m} / \mathrm{s}$ in comparison to the mean values within the NGB (see comparison of light blue and dark blue lines in Fig. 7b).

\section{Upper Cretaceous burial anomaly}

Sonic velocities within Upper Cretaceous Chalk are intensely studied and could be used as a proxy for vertical movements (e.g. Japsen 2018). Figure 7a shows a comparison between our results for seismic layer 3 (interpreted as Upper Cretaceous units) with the Upper CretaceousDanian Chalk Group within the North Sea Basin (Japsen 2000). The depth-depending velocity trend of the Upper Cretaceous in the Bay of Mecklenburg is approx. $450 \mathrm{~m} / \mathrm{s}$ higher than the trend derived for the North Sea Basin (red arrow in Fig. 7a). With respect to the gradient for this layer $\left(1.01 \mathrm{~s}^{-1}\right.$, see Table 1$)$, this velocity anomaly corresponds to a burial anomaly of about $-450 \mathrm{~m}$. Hence, it suggests an exhumation/erosion event that must have taken place in post-Cretaceous times. Similar results were derived by a regional study based on Danish well data covering the whole North Sea Basin, including the area just north of the Bay of Mecklenburg (Japsen 1998). The burial anomaly for the Upper Cretaceous unit at well Rødby-1 situated on Lolland was about - $634 \mathrm{~m}$, while well Ørslev-1 located on Falster showed a burial anomaly of $-483 \mathrm{~m}$ (see Fig. 1 for location). Both values are in good agreement with the burial anomaly inferred in this study. Therefore, we can conclude that the Bay of Mecklenburg was uplifted by $450 \mathrm{~m}$ during the Cenozoic.

\section{Lower Triassic burial anomaly}

Within several previous investigations, the seismic velocities in Lower Triassic formations with respect to burial history and uplift have been analysed within the Southern Permian Basin. The Baltic Formation (Lower Buntsandstein) within the western part of the Polish Basin has been analysed by Dadlez et al. (1997). They used velocities from vertical seismic profiling at 64 wells and compared these to a representative background curve. They found velocity anomalies in the range of 500 to $700 \mathrm{~m} / \mathrm{s}$ for many of the wells and concluded that the northwestern part of the Mid-Polish Swell was uplifted by about $1500 \mathrm{~m}$ in the Upper Cretaceous. A comparable investigation was performed by van Dalfsen et al. (2005) covering sonic logs from 460 Dutch on- and offshore wells. They found velocity anomalies for the Triassic Main Claystone Member as high as $1500 \mathrm{~m} / \mathrm{s}$, related to a maximum apparent uplift of $2400 \mathrm{~m}$.

A comparison between the seismic velocities presented here for Middle and Lower Buntsandstein (black line in Fig. 7b) and the background trend for the NGB (light blue line in Fig. 7b) results in a velocity anomaly of about $640 \mathrm{~m} / \mathrm{s}$. With respect to the range of gradients within this layer ( 0.36 to $\left.0.45 \mathrm{~s}^{-1}\right)$, this corresponds to a burial anomaly in the range of -1400 to $-1700 \mathrm{~m}$. The magnitude of inferred vertical movements within the Cenozoic is not sufficient to explain a burial anomaly in this range. In the following, we discuss the possibility of additional vertical movements within early Cretaceous/late Jurassic times by using the depth values from CDP 13,200 (Fig. 4). 
Fig. 7 a Velocity distribution of Upper Cretaceous layers in comparison with a published background trend (green line) for the North Sea Chalk (Japsen 2000). Results of the MVA in this study shown by black line. The velocity anomaly between both curves (red arrow) shows a mean value of $450 \mathrm{~m} / \mathrm{s}$. The velocity anomaly was calculated at the mean depth which is covered by the layer. b Velocity with depth distribution within the Middle to Lower Buntsandstein layers in comparison with published background velocity trends from different regions: green for Norwegian-Danish Basin (Japsen and Bidstrup 1999), red for the Dutch on- and offshore (van Dalfsen et al. 2005), yellow for the Polish Basin (Dadlez et al. 1997), and blue for the northwest North German Basin (Jaritz et al. 1991); light blue represents the mean for the whole NGB; and dark blue is the approximation for the southwestern edge of the Bay of Mecklenburg. Results of the MVA in this study shown by black line. The velocity anomaly (red arrow) between our results and the mean values from Jaritz et al. (1991) is about $640 \mathrm{~m} / \mathrm{s}$
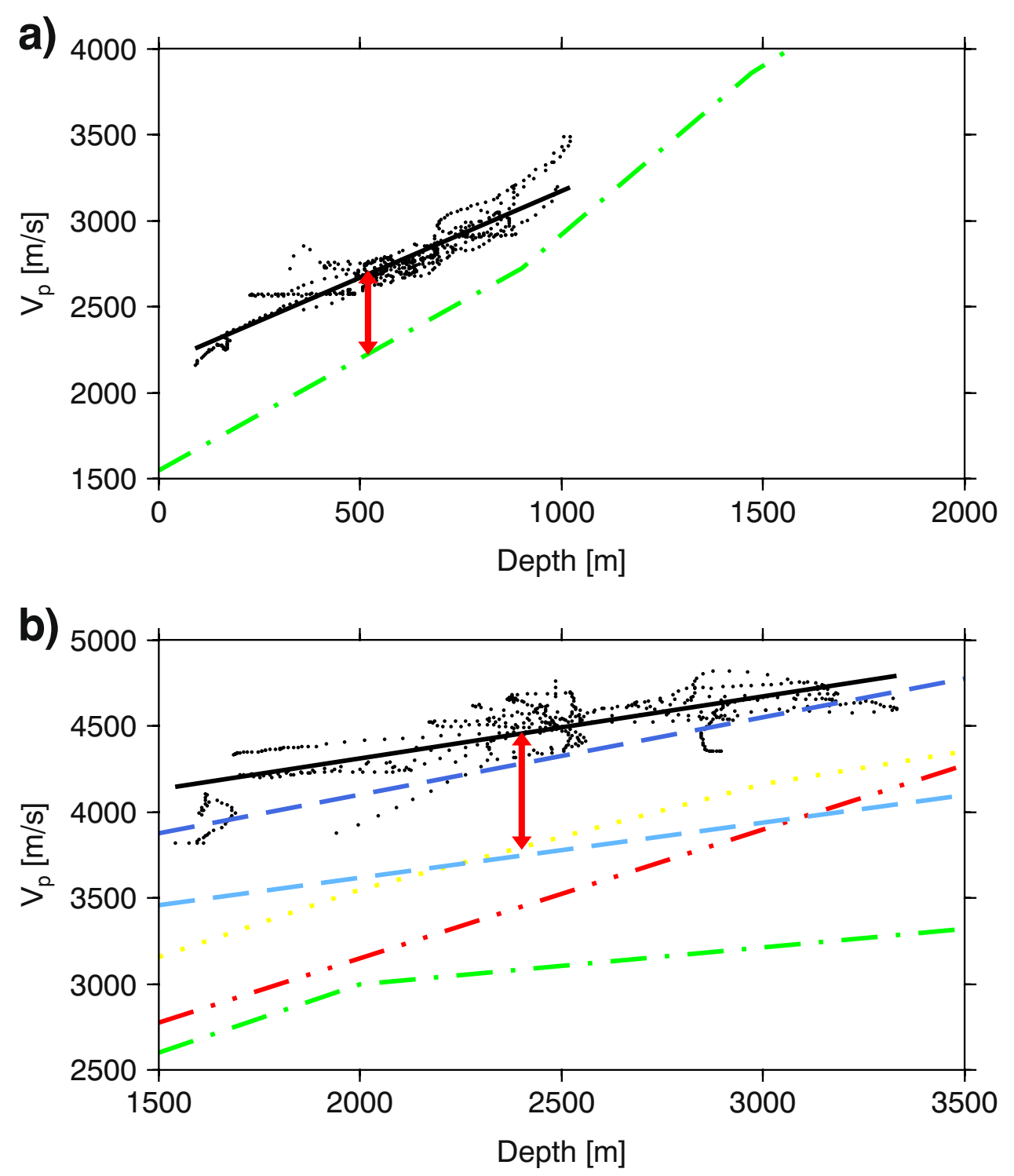

The interpretation of Fig. $4 \mathrm{~b}$ in combination with the results from Ahlrichs et al. (2020) shows that the depth of the lowermost Cretaceous successions (Albian) is at $1200 \mathrm{~m}$ below sea level. To allow for a burial anomaly between -1400 and $-1700 \mathrm{~m}$ for the Triassic units, a total amount of 2600 to $2900 \mathrm{~m}$ of sedimentary rocks had to be removed during the Lower Cretaceous/Upper Jurassic hiatus. Such an amount of uplift is not unusual. Within the Broad Fourteens Basin in the North Sea, a local uplift of Triassic units in the range of 2000 to $3500 \mathrm{~m}$ is well known (see discussion in de Jager 2003). The magnitude of this uplift was also confirmed by the analysis of seismic velocity anomalies (van Dalfsen et al. 2005). Another pre-requisite for erosion is the preceding deposition of sediments with the corresponding thickness. Processes which lead to the deposition of thick Jurassic deposits are well documented for parts of the NGB. The Jurassic doming within the North Sea was accompanied by extensional movements. Within the Danish Central Graben, this resulted in short periods (uppermost Middle Jurassic to lowermost Upper Jurassic time) of rapid subsidence with deposition of more than $4 \mathrm{~km}$ of marine mud (Andsbjerg et al. 2001). The local deposition of thick Jurassic sediments in the vicinity of rift structures within the NGB is also well documented. Warsitzka et al. (2017) discuss Jurassic sedimentation in conjunction with the Glückstadt Graben, just west of the Bay of Mecklenburg. In the west of the Glückstadt Graben, the existence of up to 3000-m thick Jurassic successions was proven by Maystrenko et al. (2011), and the eastward-directed late Jurassic erosion of these Jurassic layers was shown by Maystrenko et al. (2005).

Within the literature, different estimates concerning the total amount of Jurassic erosion within the NGB are reported. For the area of the German-Danish Horn-Graben, Kilhams et al. (2018) estimated the amount of missing 
Jurassic material to not exceed $500 \mathrm{~m}$. Rodon and Littke (2005) have performed numerical modelling for well data from Fehmarn Z1. Their model incorporated an amount of eroded Lower and Middle Jurassic rocks of about $700 \mathrm{~m}$ - this value was originally proposed by Jaritz (1980). However, the modelling results from Rodon and Littke (2005) show that the measured values for the vitrinite reflectance are also in agreement with an amount of Jurassic erosion in the range of $1400 \mathrm{~m}$. The removal of Jurassic rocks at the well Tønder-2 was analysed by Japsen et al. (2007). While the estimation of eroded material based on sonic data resulted in a value of $1200 \mathrm{~m}$, the application of apatite fission track analysis resulted in a value of $3000 \mathrm{~m}$.

Due to missing well data within the Bay of Mecklenburg, we could not exclude lithological variations within the Triassic layers in the Bay of Mecklenburg in comparison to the central NGB. But with respect to existing results, it seems reasonable that the here reported negative burial anomaly within the Buntsandstein layers could be caused by early Cretaceous/late Jurassic erosion with a magnitude between 2600 and $2900 \mathrm{~m}$. This is further supported by paleogeographic maps (Ziegler 1990a): the area of the Bay of Mecklenburg was uplifted during Bajocian as the easternmost part of the Central North Sea Dome and remained subaerial until the Barremian as the northern part of the Pombeckj Swell.

\section{Heterogeneity within the Zechstein}

Our data has shown that the velocity within the Zechstein inversely correlates with the thickness of this layer. This effect has previously been shown by an evaluation of Dutch wells (Wong et al. 2004), but here, we show this effect for the first time with indirect (surface-based seismic) methods. Interestingly, the velocity trend from our work is in very good agreement with the findings from Wong et al. (2004) (see Fig. 6). Besides the general increase of Zechstein thickness towards the basin centre, thickness in the Bay of Mecklenburg varies locally due to salt accumulation in salt pillows and depletion in adjacent rim synclines (e.g. Zöllner et al. 2008; Ahlrichs et al. 2020). As salt pillows grow, the lower viscous portions of the Zechstein evaporite sequence (mostly halite) accumulate in the structure, while the higher viscous portions (mostly anhydrite and non-evaporite rocks) remain in the area of salt depletion. Accordingly, the relative content of halite in the Zechstein succession varies with thickness in the area of investigation. The difference in the physical properties of halite, anhydrite and non-evaporites impacts the interval velocity of the layer as generally anhydrite and non-evaporites $(5000-6500 \mathrm{~m} / \mathrm{s})$ are characterized by higher interval velocities than halite $(4500 \mathrm{~m} / \mathrm{s})$ (e.g. Urai et al. 2008). Therefore, thinner layers have a higher relative content of anhydrite and non-evaporites, which increases the interval velocity of this layer.

\section{Conclusions}

Within this study, we presented a consistent laterally variant seismic interval velocity model covering Cenozoic and Mesozoic successions. This model helps to depth-convert seismic data in the area of the Bay of Mecklenburg. Further on, we showed that seismic velocities deduced from surface-based measurements, like seismic imaging, can help to understand the evolution of sedimentary basins. We analysed the velocity model to derive depth-dependent velocity trends for the Bay of Mecklenburg and compared them to published reference trends from adjacent areas. Our interpretation of velocity anomalies as a proxy of maximum burial depth modified by vertical tectonic movement results in the conclusions concerning the Bay of Mecklenburg:

- The Upper Cretaceous successions show a velocity anomaly of about $450 \mathrm{~m} / \mathrm{s}$. This anomaly is interpreted to be caused by Cenozoic uplift with a magnitude of about $450 \mathrm{~m}$. This interpretation is supported by results from well data just north of the Bay of Mecklenburg.

- The Lower Jurassic successions show a velocity anomaly of about $640 \mathrm{~m} / \mathrm{s}$. This anomaly could be caused by an uplift of about 2600 to $2900 \mathrm{~m}$ in early Cretaceous/ late Jurassic times. Due to missing well data within the Bay of Mecklenburg, lithological variations causing this velocity anomaly cannot be excluded.

- Within the Zechstein unit and as a result of the different rheology, the relative fraction of halite compared to anhydrite is depleted between the salt pillows. This leads to an increase in the interval velocity.

We have shown that seismic velocities derived from migration velocity analysis (MVA) are sensitive enough for a geological interpretation concerning the uplift history. For this analysis, only a basic knowledge about the background velocity trends is needed. Therefore, the here presented method can be used to enhance the spatial coverage as well as the lateral resolution of velocity fields in areas with sparse drilling information.

Acknowledgements We thank master Ralf Schmidt and his crew for their professional work during cruise MSM 52. Comments from Fabian Jähne-Klingberg and Martin Engels helped to improve an earlier version of the manuscript. Figures were generated using GMT (Wessel and Smith 1998) and Seismic Unix (Stockwell 1999).

Funding Open Access funding enabled and organized by Projekt DEAL. 
Data availability The processed seismic data is available via the panEuropean data portal Geo-Seas, https://www.geo-seas.eu/search/welco me.php?query $=1678 \&$ query_code $=\{558 \mathrm{D} 29 \mathrm{~F} 1-65 \mathrm{~F} 5-4441-8 \mathrm{CAF}-$ $8 \mathrm{E} 15926546 \mathrm{E} 9\}$. Additional raw data is available from the corresponding author upon request.

Open Access This article is licensed under a Creative Commons Attribution 4.0 International License, which permits use, sharing, adaptation, distribution and reproduction in any medium or format, as long as you give appropriate credit to the original author(s) and the source, provide a link to the Creative Commons licence, and indicate if changes were made. The images or other third party material in this article are included in the article's Creative Commons licence, unless indicated otherwise in a credit line to the material. If material is not included in the article's Creative Commons licence and your intended use is not permitted by statutory regulation or exceeds the permitted use, you will need to obtain permission directly from the copyright holder. To view a copy of this licence, visit http://creativecommons.org/licenses/by/4.0/.

\section{References}

Ahlrichs N, Hübscher C, Noack V, Schnabel M, Damm V, Krawczyk CM (2020) Structural evolution at the northeast North German Basin margin: from initial Triassic salt movement to Late Cretaceous-Cenozoic remobilization. Tectonics 39:e2019TC005927. https://doi.org/10.1029/2019TC005927

Al-Yahya K (1989) Velocity analysis by iterative profile migration. Geophysics 54:718-729. https://doi.org/10.1190/1.1442699

Andsbjerg J, Nielsen LH, Johannessen PN, Dybkjær K (2001) Divergent development of two neighbouring basins following the jurassic north sea doming event: the Danish Central Graben and the Norwegian-Danish Basin. In: Martinsen OJ, Dreyer T (eds) Norwegian Petroleum Society Special Publications, vol 10. Elsevier, Amsterdam, pp 175-197. https://doi.org/10.1016/S0928-8937(01) 80013-8

Bachmann GH, Voigt T, Bayer U, von Eynatten H, Legler B, Littke R (2008) Depositional history and sedimentary cycles in the central European basin system. In: Littke R, Bayer U, Gajewski D, Nelskamp S (eds) Dynamics of complex intracontinental basins: the example of the central European basin system. Springer, pp 156-172. https://doi.org/10.1007/978-3-540-85085-4_4

Baldschuhn R, Binot F, Fleig S, Kockel F (2001) Geotektonischer Atlas von Nordwest-Deutschland und dem deutschen Nordseesektor. Geol Jahr Reihe A 153:3-95

Corcoran DV, Doré AG (2005) A review of techniques for the estimation of magnitude and timing of exhumation in offshore basins. Earth Sci Rev 72:129-168. https://doi.org/10.1016/j.earscirev. 2005.05.003

Dadlez R, Jóźwiak W, Młynarski S (1997) Subsidence and inversion in the western part of Polish Basin - data from seismic velocities. Geol Q 41:197-208

de Jager J (2003) Inverted basins in the Netherlands, similarities and differences. Netherlands Journal of Geosciences - Geologie en Mijnbouw 82:339-349. https://doi.org/10.1017/S001677460 0020175

Densley MR, Hillis RR, Redfearn JEP (2000) Quantification of uplift in the Carnarvon basin based on interval velocities. Aust J Earth Sci 47:111-122. https://doi.org/10.1046/j.1440-0952.2000.00765.x

Erlström M (2020) Carboniferous-Neogene tectonic evolution of the Fennoscandian transition zone, southern Sweden. Geol Soc Lond Mem 50:603-620. https://doi.org/10.1144/m50-2016-25
Etgen J, Gray SH, Zhang Y (2009) An overview of depth imaging in exploration geophysics. Geophysics 74:WCA5-WCA17. https:// doi.org/10.1190/1.3223188

Faust LY (1951) Seismic velocity as a function of depth and geologic time. Geophysics 16:192-206. https://doi.org/10.1190/1.1437658

Feßer S (1980) Bohrloch Gutachten Vertikalprofilierung Brg. Objekt 101. VEB Geophysik, Leipzig

Hoth K, Rusbült J, Zagora K, Beer H, Hartmann O (1993) Die tiefen Bohrungen im Zentralabschnitt der Mitteleuropäischen Senke - Dokumentation für den Zeitabschnitt 1962-1990. Verlag der Gesellschaft für Geologische Wissenschaften, Berlin

Hansen MB, Scheck-Wenderoth M, Hübscher C, Lykke-Andersen H, Dehghani A, Hell B, Gajewski D (2007) Basin evolution of the northern part of the Northeast German Basin - insights from a 3D structural model. Tectonophysics 437:1-16. https://doi.org/ 10.1016/j.tecto.2007.01.010

Hübscher C et al. (2017) BalTec - Cruise No. MSM52 - March 1 March 28, 2016 - Rostock (Germany) - Kiel (Germany). https:// doi.org/10.2312/cr_msm52

Hübscher C, Hansen MB, Triñanes SP, Lykke-Andersen H, Gajewski D (2010) Structure and evolution of the Northeastern German Basin and its transition onto the Baltic Shield. Mar Pet Geol 27:923-938. https://doi.org/10.1016/j.marpetgeo.2009.10.017

Japsen P (1993) Influence of Lithology and Neogene uplift on seismic velocities in Denmark: implications for depth conversion of maps. AAPG Bull 77:194-211

Japsen P (1998) Regional velocity-depth anomalies, North Sea Chalk: a record of overpressure and Neogene uplift and erosion. AAPG Bull 82:2031-2074

Japsen P (2000) Investigation of multi-phase erosion using reconstructed shale trends based on sonic data. Sole Pit axis. North Sea Global and Planetary Change 24:189-210. https://doi.org/ 10.1016/S0921-8181(00)00008-4

Japsen P (2018) Sonic velocity of chalk, sandstone and marine shale controlled by effective stress: velocity-depth anomalies as a proxy for vertical movements. Gondwana Res 53:145-158. https://doi.org/10.1016/j.gr.2017.04.013

Japsen P, Bidstrup T (1999) Quantification of the late Cenozoic erosion in Denmark based on sonic data and basin modelling. Bull Geol Soc Den 46:79-99

Japsen P, Mukerji T, Mavko G (2007) Constraints on velocity-depth trends from rock physics models. Geophys Prospect 55:135154. https://doi.org/10.1111/j.1365-2478.2007.00607.x

Jaritz W (1980) Einige Aspekte der Entwicklungsgeschichte der nordwestdeutschen Salzstöcke. Zeitschrift der Deutschen Geologischen Gesellschaft 131:307-408

Jaritz W, Best G, Hildebrand G, Jürgens U (1991) Regionale Analyse der seismischen Geschwindigkeiten in Nordwestdeutschland. Geol Jahrb 45:23-57

John H (1975) Hebungs- und Senkungsvorgänge in Nordwestdeutschland. Erdöl und Kohle 28:273-277

Kilhams B, Stevanovic S, Nicolai C (2018) The 'Buntsandstein' gas play of the Horn Graben (German and Danish offshore): dry well analysis and remaining hydrocarbon potential. Geological Society, London, Special Publications 469:169-192. https://doi. org/10.1144/sp469.5

Kley J (2018) Timing and spatial patterns of Cretaceous and Cenozoic inversion in the Southern Permian Basin. Geological Society, London, Special Publications 469:19-31. https://doi.org/ $10.1144 / \mathrm{sp} 469.12$

Kley J, Voigt T (2008) Late Cretaceous intraplate thrusting in central Europe: effect of Africa-Iberia-Europe convergence, not Alpine collision. Geology 36:839-842. https://doi.org/10.1130/g2493 0a.1

Kossow D, Krawczyk CM (2002) Structure and quantification of processes controlling the evolution of the inverted NE-German 
Basin. Mar Pet Geol 19:601-618. https://doi.org/10.1016/S02648172(02)00032-6

Marsden D (1992) $\mathrm{V}_{\mathrm{o}}-\mathrm{K}$ method of depth conversion. Leading Edge 11:53-54

Maystrenko Y, Bayer U, Scheck-Wenderoth M (2005) The Glueckstadt Graben, a sedimentary record between the North and Baltic Sea in north central Europe. Tectonophysics 397:113-126. https://doi. org/10.1016/j.tecto.2004.10.004

Maystrenko Y, Bayer U, Brink H-H, Littke R (2008) The central European basin system - an overview. In: Littke R, Bayer U, Gajewski D, Nelskamp S (eds) Dynamics of complex intracontinental basins: the central European basin system. Springer, pp 15-34. https://doi.org/10.1007/978-3-540-85085-4_2

Maystrenko Y, Bayer U, Scheck-Wenderoth M (2011) 3D structural model of the Glueckstadt Graben. NW Germany Deutsches GeoForschungsZentrum GFZ, Potsdam. https://doi.org/10.2312/GFZ. b103-11084

Mazur S, Dunlap WJ, Turniak K, Oberc-Dziedzic T (2006) Age constraints for the thermal evolution and erosional history of the central European Variscan belt: new data from the sediments and basement of the Carboniferous foreland basin in western Poland. J Geol Soc 163:1011-1024. https://doi.org/10.1144/0016-76492 004-170

Menning M (2018) The stratigraphic table of Germany 2016 (STG 2016). German J Geol 169:105-128. https://doi.org/10.1127/zdgg/ 2018/0161

Nielsen LH, Japsen P (1991) Deep wells in Denmark 1935 - 1990: lithostratigraphic subdivision vol 31. Danmarks Geologiske Undersøgelse Serie A:31. København

Reinhardt H-G (1993) Structure of Northeast Germany: regional depth and thickness maps of Permian to tertiary intervals compiled from seismic reflection data. In: Spencer AM (ed) Generation, accumulation and production of Europe's hydrocarbons III. Springer, Berlin, pp 155-165. https://doi.org/10.1007/978-3-642-77859-9

Rodon S, Littke R (2005) Thermal maturity in the central European basin system (Schleswig-Holstein area): results of 1D basin modelling and new maturity maps. Int J Earth Sciences 94:815-833. https://doi.org/10.1007/s00531-005-0006-1

Scheck-Wenderoth M, Maystrenko Y, Hübscher C, Hansen M, Mazur S (2008) Dynamics of salt basins. In: Littke R, Bayer U, Gajewski D, Nelskamp S (eds) Dynamics of complex intracontinental basins: the central European basin system. Springer, pp 307-322. https://doi.org/10.1007/978-3-540-85085-4_6

Scheck M, Bayer U (1999) Evolution of the Northeast German Basin - inferences from a 3D structural model and subsidence analysis. Tectonophysics 313:145-169. https://doi.org/10.1016/S00401951(99)00194-8

Scherbaum F (1982) Seismic velocities in sedimentary rocks — indicators of subsidence and uplift? Geol Rundsch 71:519-536. https:// doi.org/10.1007/bf01822381

Schlüter H-U, Best G, Jürgens U, Binot F (1997a) Interpretation reflexionsseismischer Profile zwischen baltischer Kontinentalplatte und kaledonischem Becken in der südlichen Ostsee - erste Ergebnisse. Zeitschrift der Deutschen Geologischen Gesellschaft 148:1-32. https://doi.org/10.1127/zdgg/148/1997/1

Schlüter H-U, Jürgens U, Best G, Binot F, Stamme H (1997b) Analyse geologischer und geophysikalischer Daten aus der südlichen Ostsee (SASO). Bundesanstalt für Geowissenschaften und Rohstoffe, Hannover
Seidel E, Meschede M, Obst K (2018) The Wiek fault system east of Rügen Island: origin, tectonic phases and its relationship to the trans-European suture zone. Geological Society, London, Special Publications 469:59-82. https://doi.org/10.1144/sp469.10

Stockwell JW (1999) The CWP/SU: Seismic Un*x package. Comput Geosci 25:415-419. https://doi.org/10.1016/S0098-3004(98) 00145-9

Stork C (1992) Reflection tomography in the postmigrated domain. Geophysics 57:680-692. https://doi.org/10.1190/1.1443282

Strohmenger C, Voigt E, Zimdars J (1996) Sequence stratigraphy and cyclic development of Basal Zechstein carbonate-evaporite deposits with emphasis on Zechstein 2 off-platform carbonates (Upper Permian, Northeast Germany). Sed Geol 102:33-54. https://doi. org/10.1016/0037-0738(95)00058-5

Tucker ME (1991) Sequence stratigraphy of carbonate-evaporite basins: models and application to the Upper Permian (Zechstein) of northeast England and adjoining North Sea. J Geol Soc 148:1019-1036. https://doi.org/10.1144/gsjgs.148.6.1019

Underhill JR, Partington MA (1993) Jurassic thermal doming and deflation in the North Sea: implications of the sequence stratigraphic evidence. Geological Society, London, Petroleum Geology Conference series 4:337-345. https://doi.org/10.1144/00403 37

Urai JL, Schléder Z, Spiers CJ, Kukla PA (2008) Flow and transport properties of salt rocks. In: Littke R, Bayer U, Gajewski D, Nelskamp S (eds) Dynamics of complex intracontinental basins: the central European basin system. Springer, pp 277 - 290. https://doi. org/10.1007/978-3-540-85085-4_5

van Dalfsen W, Mijnlieff HF, Simmelink HJ (2005) Interval velocities of a Triassic claystone: key to burial history and veloctiy modelling. Paper presented at the EAGE $67^{\text {th }}$ Conference \& Exhibition, Madrid, 13 - 16 June 2005

Warsitzka M, Kley J, Jähne-Klingberg F, Kukowski N (2017) Dynamics of prolonged salt movement in the Glückstadt Graben (NW Germany) driven by tectonic and sedimentary processes. Int J Earth Sciences 106:131-155. https://doi.org/10.1007/ s00531-016-1306-3

Wessel P, Smith WHF (1998) New, improved version of generic mapping tools released. EOS Trans Am Geophys Union 79:579-579. https://doi.org/10.1029/98EO00426

Wong TE et al (2004) Geological atlas of the subsurface of the Netherlands: onshore. Netherlands Inst. of Appl, Geoscience TNO, Utrecht

Ziegler PA (1990a) Geological atlas of western and central Europe, 2nd edn. Shell Internationale Petroleum Maatschappij, The Hague

Ziegler PA (1990b) Tectonic and Palaeogeographic development of the North Sea rift system. In: Blundell DJ, Gibbs AD (eds) Tectonic evolution of the North Sea rifts. Clarendon Press, Oxford, pp 1-36

Zöllner H, Reicherter K, Schikowsky P (2008) High-resolution seismic analysis of the coastal Mecklenburg Bay (North German Basin): the pre-Alpine evolution. Int J Earth Sciences 97:1013-1027. https://doi.org/10.1007/s00531-007-0277-9

Publisher's note Springer Nature remains neutral with regard to jurisdictional claims in published maps and institutional affiliations. 